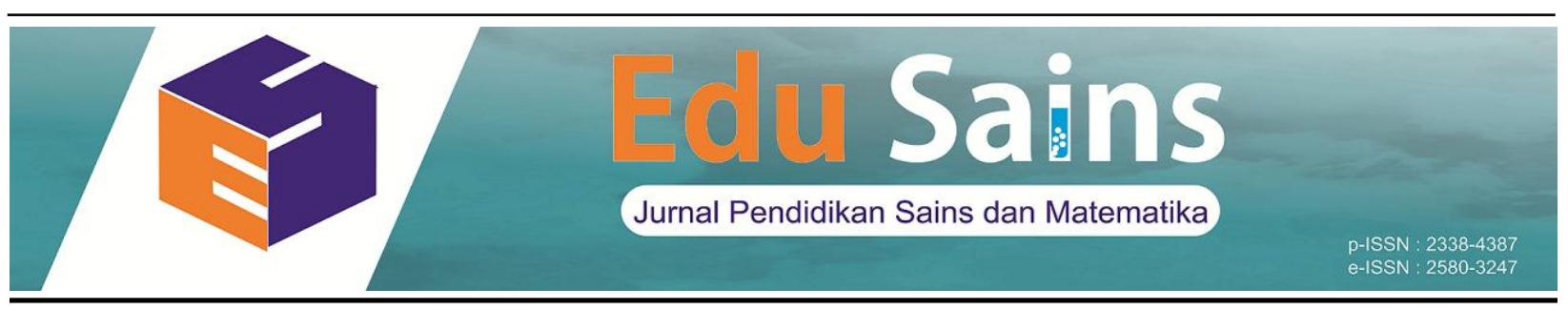

\title{
KETERAMPILAN BERPIKIR KREATIF MAHASISWA CALON GURU BIOLOGI PADA KONSEP BIOTA LAUT MENUJU PEMBANGUNAN BERKELANJUTAN MELALUI PEMBELAJARAN BERBASIS PROYEK
}

\author{
Jumrodaha* $^{\mathrm{a}}$, Liliasari ${ }^{\mathrm{b}}$, Yusuf Hilmi Adisendjajac, Yayan Sanjayad \\ E-mail: jumrodah@iain-palangkaraya.ac.id \\ ${ }^{*}$ Tadris Biologi, Institut Agama Islam Negeri Palangka Raya, Palangka Raya, Indonesia \\ ${ }_{a *, b, c, d}$ Pendidikan IPA, Sekolah Pascasarjana, Universitas Pendidikan Indonesia, Bandung, Indonesia
}

\begin{abstract}
Abstrak
Penelitian ini bertujuan untuk mengetahui peningkatan keterampilan berpikir kreatif pada materi biota laut menuju pembangunan berkelanjutan melalui pembelajaran berbasis proyek pada mahasiswa calon guru biologi. Penelitian ini menggunakan metode quasi eksperimen dengan one group pretest postest design. Subyek terdiri dari 31 mahasiswa yang memprogramkan mata kuliah ekologi laut pada semester 5 di salah satu universitas Kalimantan Tengah. Instrument tes yang digunakan berupa soal test pilihan ganda (PG) beralasan dan soal test uraian. Kegiatan pembelajaran dilaksanakan empat tahap yaitu (1) mahasiswa diminta untuk mendesain proyek yang dilakukan, 2) mempresentasikan teori dan rancangan terkait proyek yang akan dilakukan, (3) melakukan implementasi proyek yang sudah dirancang dan pengamatannya, (4) melaporkan hasil implementasi proyek sekaligus mengevaluasi untuk kegaiatan proyek selanjtnya. Hasil penelitian menunjukan bahwa setiap indikator keterampilan berpikir kreatif yang diamati yaitu flexibility, originality dan elaboration menunjukkan adanya perbedaan signifikan antara pretes dan postest. Hasil ini dapat dikatakan bahwa pembelajaran berbasis proyek pada konsep biota laut menuju pembangunan berkelanjutan dapat meningkatkan keterampilan berpikir kreatif.
\end{abstract}

Kata Kunci: keterampilan berpikir kreatif, biota laut, berbasis proyek.

\begin{abstract}
This study aims to investigate the improvement of creative thinking skills of Biology student teachers on the concept of marine biota sustainable development material through project-based learning. This study used a quasi-experimental method with one group pretest-posttest design. A total of 31 Biology student teachers in one of Central Kalimantan Universities who were studying marine ecology participated in this study. The instrument used two-tier multiple choice test and essay. Teaching and learning activities in this study covered four stages: 1) designing project plan, 2) presenting the theories and the design of the project, 3) implementing the designed project and observations, 4) reporting the results of project implementation and evaluating for subsequent project activities. The results showed that every indicator of creative thinking skills in the aspect of flexibility, originality and elaboration had a significant difference between the pretest and posttest. These indicated that project-based learning on the concept of marine biota sustainable development is effective to improve students' creative thinking skills.
\end{abstract}

Keywords: creative thinking skills, marine biota, project-based

98 I Institut Agama Islam Negeri Palangka Raya, Jl. G. Obos Komplek Islamic Centre Palangka Raya, Kalimantan Tengah, Indonesia

Universitas Pendidikan Indonesia, Jl. Dr. Setiabudhi No. 229, Bandung, Jawa Barat, Indonesia 


\section{PENDAHULUAN}

Salah satu tujuan pendidikan di universitas adalah membekalkan keterampilan berpikir tingkat tinggi, misalnya berpikir kreatif. Keterampilan berpikir kreatif menjadi sangat penting yang harus dimiliki oleh peserta didik, karena keterampilan berpikir kreatif merupakan salah satu kompetensi pembelajaran pada abad 21. Membekalkan keterampilan berpikir kreatif pada pembelajaran sains dapat memberikan kontribusi positif pada pengembangan pribadi, sosial, teknologi dan ekonomi yang akan mereka lakukan sebagai orang dewasa di abad ke-21 (Trnova, 2014; Diawati et al, 2017; Mulyono, 2018). Keterampilan berpikir kreatif menjadi salah satu faktor kunci penting untuk mengatasi berbagai permasalahan kompleks di era industri 4.0 (Santoso dan Wulandari, 2020; Rif'at et al., 2020; Zainuddin et al., 2020; Yanti et al., 2020). Tujuan pendidikan di abad 21 harus mengacu pada sustainable development goals (SDGs) (UNESCO, 2017). Selain itu juga mampu menjadikan peserta didik berpikir kreatif dalam hal memecahkan dan menyelesaikan masalah pada situasi sulit yang dihadapi maupun keterampilan mengkomunikasikannya (Armandita et al, 2017; Santoso dan Wulandari, 2020). Untuk menghadapi era revolusi industri 4.0, maka diperlukan pembelajaran yang dapat membentuk generasi kreatif, inovatif dan kompetitif (Sobri et al, 2020). Pembelajaran berbasis proyek merupakan pembelajaran inovatif yang melatih berbagai strategi penting untuk dapat sukses di abad ke-21 (Zubaedah, 2019). Pembelajaran berbasis proyek dapat dikatakan bahwa pembelajaran difokuskan untuk mengembangkan kompetensi dengan memilih topik, menganalisis masalah, memecahkan masalah, mengambil keputusan, memberikan kesempatan untuk merancang desain proyek secara mandiri dan menghasilkan proyek nyata yang dapat dimanfaatkan untuk kehidupan manusia. Biota laut merupakan salah satu materi pada mata kuliah ekologi laut yang menuntut mahasiswa untuk berpikir kreatif. Materi ini menjadi menarik dikarenakan beberapa sumber hayati laut yang memiliki peran dan manfaat baik secara ekologi maupun ekonomi, tetapi belum banyak dimanfaatkan secara berkelanjutan.

Para peneliti sebelumnya telah mengembangkan pembelajaran berbasis proyek untuk meningkatkan keterampilan berpikir kreatif baik pada materi eksakta maupun non eksakta di perguruan tinggi maupun sekolah-sekolah. Pembelajaran berbasis proyek untuk meningkatkan keterampilan berpikir kreatif dan sikap ilmiah pada materi nutrisi menekankan kegiatan praktikum dengan menentukan bahan baku lokal untuk mengolah makanan yang sehat, unik, bergizi, serta bernilai ekonomis (Susanti, 2013). Peneliti lain menerapkan pembelajaran berbasis proyek membuat alat sederhana yang dapat mendeteksi larutan bersifat asam dan basa serta dari alat tersebut dapat menentukan trayek pH dari indikator alami yang telah dibuat (Candra et al, 2019). Penelitian lain melakukan karakterisasi dengan berfokus mendesain alat yang digunakan untuk menyaring air secara efektif dan efisien (Ridho et al, 2020). Sementara itu peneliti lain meningkatkan keterampilan berpikir kreatif melalui kegiatan mendesain produk sebagai upaya untuk memecahkan masalah terkait dengan pencemaran lingkungan (Yamin et al, 2020). Kemampuan mengungkapkan gagasan atau ide yang baik dapat mempengaruhi kemampuan berpikir kreatif peserta didik (Candra et al, 2019). Aspek-aspek dalam kemampuan berpikir kreatif yang menjadi fokus dalam penelitian ini adalah kemampuan berpikir luwes, kemampuan berpikir orisinil dan kemampuan merinci. Banyak penelitian yang sudah dikembangkan terkait pembelajaran berbasis proyek dengan keterampilan berpikir kreatif, namun belum ditemukan pembelajaran berbasis proyek dengan 
mendesain kegiatan budidaya biota laut secara ex-situ dan mengembangkan keterampilan berpikir kreatif dengan menganalisis masalah dan mencari solusinya terkait dengan budidaya biota laut yang berkelanjutan.

Beberapa hal yang harus diperhatikan sebelum melakukan pembelajaran berbasis proyek untuk meningkatkan keterampilan berpikir kreatif pada materi biota laut adalah menyiapkan perangkat pembelajaran yang terdiri dari satuan acara pembelajaran, materinya, LKM dan instrument test serta sarana dan prasarana laboratorium untuk budidaya biota laut khususnya fitoplankton. Sebelum kegiatan budidaya dilakukan, mahasiswa diharuskan untuk mendesain tahapan-tahapan budidaya fitoplankton dengan menganalisis faktor-faktor eksternal yang mempengaruhi pola hidup fitoplankton. Berdasarkan uraian diatas maka tujuan penelitian ini diharapkan dapat meningkatkan keterampilan berpikir kreatif pada konsep biota laut menuju pembangunan berkelanjutan melalui pembelajaran berbasis proyek pada mahasiswa calon guru biologi.

Pembelajaran berbasis proyek bersifat kolaboratif untuk meningkatkan inovasi dalam menghasilkan tugas proyek (Rambely et al, 2013; Xu \& Liu, 2010). Sehingga dapat ditegaskan bahwa pembelajaran berbasis proyek merupakan pembelajaran yang diorientasikan untuk mengerjakan sebuah proyek yang bermanfaat untuk menyelesaikan permasalahan masyarakat atau lingkungan, melalui pengembangan pengetahuan dan keterampilan para peserta didik dengan serangkaian kegiatan menganalisis dan memecahkan masalah merencanakan, melaksanakan penelitian, berkomunikasi dan membuat keputusan serta menghasilkan proyek tertentu yang dibingkai dalam satu wadah berupa proyek perkuliahan yang diintegrasikan dengan kegiatan praktikum laboratorium dengan teori. Pembelajaran berbasis proyek (PjBL) yang diadopsi dari Colley (2008). Penelitian ini bertujuan untuk mengetahui peningkatan keterampilan berpikir kreatif pada materi biota laut menuju pembangunan berkelanjutan melalui pembelajaran berbasis proyek pada mahasiswa calon guru biologi.

\section{METODE}

Penelitian ini dilaksanakan pada salah satu universitas di palangkaraya, populasi penelitian adalah mahasiswa yang sedang memprogramkan mata kuliah ekologi laut di semester lima angkatan 2017/2018, dengan sampel penelitian sebanyak 31 mahasiswa. Metode yang digunakan adalah quasi ekperiment dengan pretest-postest design.

Penelitian ini dilakukan dengan tahap persiapan, pelaksanaan, pengambilan data, analisis, pembahasan, kemudian pengambilan kesimpulan. Teknik pengumpulan data dilakukan dengan soal test keterampilan berpikir kritis dengan aspek yang diukur flexibility, originality dan elaboration (Torrance, 1966). Soal test ada dua jenis yang digunakan yaitu PG beralasan dan uraian. Pengolahan data dilakukan dengan menghitung rerata pretest dan postest kemudian dilanjutkan dengan uji statistik normalitas (Shapiro-Wilk) dan homogenitas (Levene test), setelah itu baru dilakukan uji beda rerata atau uji hipotesis dengan menggunakan software IBM SPSS versi 20.

Langkah-langkah pembelajaran berbasis proyek pada materi biota laut mengadopsi Colley (2008) terdapat enam siklus pembelajaran berbasis proyek: orientasi pembelajaran berbasis proyek pada bidang sains baik secara umum maupun spesifik, mengidentifikasi dan mendefinisikan proyek, merencanakan proyek, melaksanakan proyek, mendokumentasikan dan melaporkan temuan proyek, dan mengevaluasi proyek dan mengambil tindakan serta mengusulkan sebuah proyek baru. 


\section{HASIL DAN PEMBAHASAN}

Hasil peningkatan keterampilan berpikir kreatif materi biota laut diperoleh data rerata pretest dan postest. Data peningkatan pretest dan postest dapat dilihat pada Gambar 1.

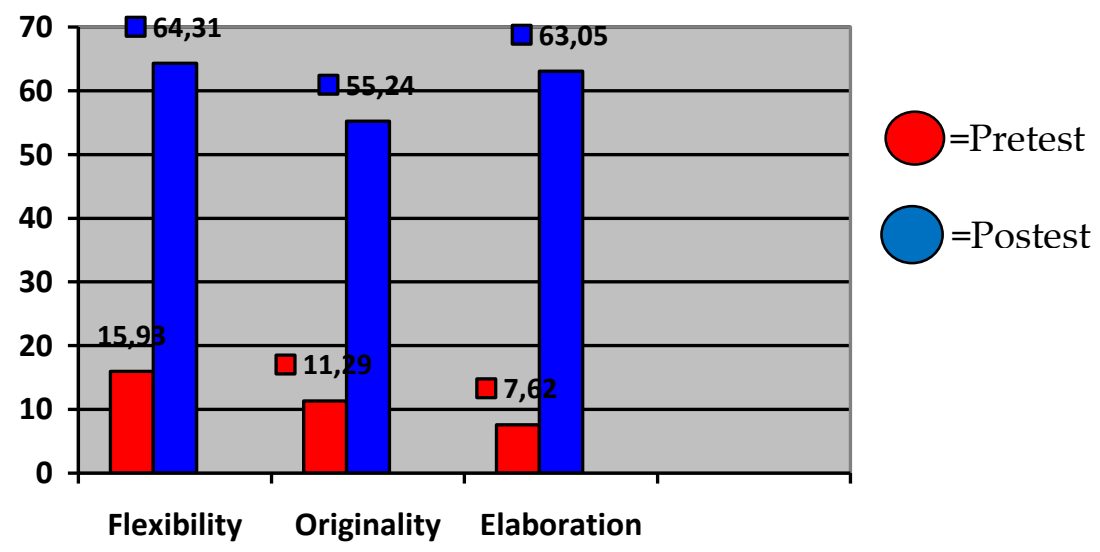

Gambar 1. Data pretest dan postest di setiap indikator pada materi biota laut

Gambar 1 menunjukkan bahwa ada peningkatan hasil belajar pretest dengan postest dari ketiga indikator yaitu flexibility, originality dan elaboration. Nilai hasil belajar pretest terendah terdapat pada indikator elaboration yaitu dengan rerata nilai 7,62, sedangkan pretest tertinggi pada indikator flexibility dengan nilai rerata 15,93 . Untuk nilai hasil belajar postest terendah terdapat pada indikator originality yaitu rerata nilainya 55,24, sedangkan postest tertinggi pada indikator flexibility dengan rerata nilai 64,32 .

Pada indikator elaboration hasil belajar pretest terendah, hal ini disebabkan pengetahuan awal mahasiswa sangat kurang pada budidaya fitoplankton di laboratorium, selain itu juga merupakan pengalaman baru karena sebelumnya belum pernah melakukan budidaya fitoplankton di laboratorium. Hasil temuan ini memperkuat temuan sebelumnya yang dikumpulkan melalui angket dan instrument test keterampilan berpikir kritis yang diadopsi dari Laurent Starkey bahwa pembelajaran selama ini sudah memberikan tugas, tetapi hanya dalam bentuk makalah kemudian dilakukan presentasi dan diskusi tanpa memberikan penekanan pada konsep yang belum jelas dan belum dipahami, sehingga keterampilan berpikir kreatif mahasiswa masih rendah, selain itu juga pembelajaran berbasis proyek selama ini belum menghasilkan proyek yang bermanfaat secara berkelanjutan (Jumrodah et al, 2019).

Item test pada indikator elaboration banyak difokuskan tentang bagaimana mendesain budidaya fitoplankton di laboratorium dengan mengaitkan faktor-faktor eksternal. Item-item test tersebut menuntut mahasiswa mampu menganalisis pola hidup fitoplankton yang dipengaruhi oleh suhu, salinitas, $\mathrm{pH}$, intensitas cahaya, nutrisi dan oksigen. Selain memecahkan masalah, mahasiswa juga dituntut untuk memberikan gagasan baru terkait budidaya fitoplankton di laboratorium. Dengan demikian mahasiswa memiliki pengetahuan yang mendalam dan utuh tentang budidaya fitoplankton, kegiatan ini menjadi menarik apabila dibekalkan kepada mahasiswa. Nampaknya kegiatan tersebut belum dibekalkan, hal ini terlihat dari perolehan hasil pretest yang rendah. Kegiatan elaboration berkaitan dengan kemampuan berpikir detail dan sistematis, sehingga dapat dilakukan dengan mengembangkan ide yang sudah ada dan memberikan gagasan atau pemecahan masalah (Wahyudi, 2020). 
Berdasarkan Gambar 1 indikator flexibility merupakan hasil belajar postest tertinggi, ini berarti mahasiswa mampu memberikan penafsiran yang beragam terhadap masalah, jika diberikan suatu masalah biasanya dapat memberikan berbagai macam cara yang berbeda untuk menyelesaikannya. Item test pada flexibility berfokus pada analisis dampak dan penyebab yang ditimbulkan karena adanya eurotrifikasi serta mampu memberikan jawaban yang tepat terkait faktor eksternal yang harus diperhatikan saat melakukan budidaya fitoplankton di laboratorium. Ini menunjukkan bahwa keterampilan berpikir kreatif sudah lebih baik saat kegiatan postest. Mahasiswa mampu memberikan gagasan yang yang bervariasi dalam menyelesaikan masalah. Pendapat ini sejalan dengan Wahyudi (2020) mahasiswa dapat secara luwes melihat permasalahan dari banyak alternative atau arah yang berbeda-beda. Selain itu juga keterampilan berpikir kreatif terbentuk pada mahasiswa apabila sering dilatih, karena keterampilan berpikir tidak akan terbentuk pada seseorang dengan sendirinya. Pendapat ini diperkuat peneliti sebelumnya bahwa pengembangan keterampilan tingkat tinggi tidak berkembang begitu saja, tetapi melalui usaha dan ditanamkan melalui perencanaan yang matang (Ghanizadeh et al, 2020; Wahyudi, 2020). Selanjutnya untuk mengetahui perbedaan peningkatan keterampilan berpikir kreatif setelah diberikan pembelajaran dilakukan uji statistik perbedaan rerata pretes dan postest dapat dilihat pada Tabel 1. Analisis uji beda dapat dilakukan dengan menggunakan uji parametrik maupun non parametrik. Keputusan menggunakan uji parametrik atau non parametrik harus dilakukan melalui uji normalitas dan homogenitas.

Tabel 1. Analisis Statistik Deskriptif (Pretes dan Postest) di Setiap Indikator Keterampilan Berpikir Kreatif (KBKr) pada Materi Biota Laut

\begin{tabular}{|c|c|c|c|c|c|c|c|c|}
\hline Indikator & $\begin{array}{c}\text { Rerata } \\
\text { Pre dan } \\
\text { Post }\end{array}$ & $\begin{array}{c}\text { Uji } \\
\text { Noma } \\
\text { litas }\end{array}$ & $\begin{array}{c}\text { Log } \\
\text { Norma } \\
\text { litas }\end{array}$ & $\begin{array}{c}\text { Uji } \\
\text { Homo } \\
\text { genitas }\end{array}$ & $\begin{array}{c}\text { Uji } \\
\text { Hipote } \\
\text { sis (T/Z) }\end{array}$ & $\begin{array}{l}\text { Proba } \\
\text { bilitas }\end{array}$ & $\begin{array}{c}\text { Nilai } \\
\text { Medi } \\
\text { an }\end{array}$ & Ket \\
\hline \multirow[t]{2}{*}{ Flexibility } & 15,93 & 0,061 & - & 0,153 & $-17,793$ & 0,000 & - & $\begin{array}{l}\text { Berbeda } \\
\text { signifi }\end{array}$ \\
\hline & 64,31 & 0,271 & - & & & & - & $\begin{array}{l}\text { kan } \\
\text { secara } \\
\text { rerata }\end{array}$ \\
\hline \multirow[t]{2}{*}{ Originality } & 11,29 & 0,000 & 0,000 & 0,144 & $-6,881$ & 0,000 & 12,50 & $\begin{array}{l}\text { Berbeda } \\
\text { signifi }\end{array}$ \\
\hline & 55,24 & 0,002 & 0,018 & & & & 50,00 & $\begin{array}{l}\text { kan } \\
\text { secara } \\
\text { median }\end{array}$ \\
\hline \multirow[t]{2}{*}{ Elaboration } & 7,62 & 0,000 & 0,000 & 0,277 & $-6,857$ & 0,000 & 9,09 & $\begin{array}{l}\text { Berbeda } \\
\text { signifi }\end{array}$ \\
\hline & 63,05 & 0,002 & 0,106 & & & & 63,64 & $\begin{array}{l}\text { kan } \\
\text { secara } \\
\text { median }\end{array}$ \\
\hline
\end{tabular}

Pada Tabel 1 dapat disimpulkan bahwa uji beda rerata pretest dan postest pada indikator flexibility, originality dan elaboration berbeda secara signifikan artinya terdapat perbedaan hasil belajar pretes dan postest dari ketiga indikator tersebut. Pada indikator flexibility terlihat bahwa datanya berdistribusi normal dan homogen, maka dilanjutkan dengan uji beda paramaterik. Sehingga didapatkan hasil, terdapat perbedaan signifikan secara rerata antara pretest dan postest pada indikator flexibility. Pada indikator originality dan elaboration 
didapatkan data tidak normal, maka dilanjutkan dengan uji log normalitas, tetapi hasilnya tetap tidak normal. Nilai dikatakan normal apabila taraf signifikan $\alpha>0,05$. Selanjutnya dilakukan uji non parametrik, sehingga didapatkan keputusan bahwa pada indikator originality dan elaboration terdapat perbedaan signifikan secara median antara hasil belajar pretest dan postest. Hal ini menunjukkan bahwa pembelajaran berbasis poyek dapat meningkatkan keterampilan berpikir kreatif. Pendapat ini sejalan dengan penelitian yang dilakukan oleh Sari et al, (2017); Husamah (2015); Susanti (2013); Lou et al (2012)

Pada indikator flexibility dikembangkan melalui pengungkapan gagasan terkait dengan pemanenan yang tepat pada fitoplankton sebagai pakan alami untuk budidaya ikan maupun non ikan. Gagasan ini disampaikan oleh mahasiswa berdasarkan hasil pengamatan fase-fase pertumbuhan fitoplankton dilaboratorium. Pembelajaran berbasis proyek sangat efektif untuk mengembangkan kemampuan berpikir lancar dan luwes, karena siswa dituntut untuk aktif bertanya dan mengeluarkan gagasannnya (Susanti, 2013). Mahasiswa dapat menganalisis berbagai informasi yang tepat dari hasil pengamatan di laboratorium dan diajukan sebagai prosedur yang akurat untuk menyelesaikan suatu permasalahan. Temuan ini sesuai dengan penelitian Rosa dan Nursa'adah (2017) bahwa kegiatan praktikum dan pengamatan di laboratorium dapat melatih siswa berpikir kreatif, dengan melaksanakan praktikum dapat menstimulasi daya pikir dan kreasi siswa.

Pada indikator originality dikembangkan ketika mahasiswa mempelajari tahapantahapan budidaya fitoplankton. Mahasiswa dituntut untuk merancang dan mendesain tahapan-tahapan budidaya fitoplankton dilaboratorium dengan mengaitkan faktor-faktor eksternal. Misalnya kebutuhan intensitas cahaya yang digunakan untuk pertumbuhan dan perkembangan fitoplankton. Hal ini mengharuskan mahasiswa untuk dapat memikirkan cara pemberian cahaya yang tepat melalui lampu TL dengan intensitas 500-10,000 lux di ruang pembiakan fitoplankton. Faktor-faktor eksternal dapat dipenuhi dalam bentuk lain walaupun di dalam laboratorium, sehingga peserta didik berhasil melakukan budidaya fitoplankton di laboratorium dengan menyesuaikan habitat alami. Originality berkaitan dengan kemampuan untuk menghasilkan ide baru (Candra et al, 2019; Santoso dan Wulandari, 2020). Ide dan gagasan yang diperoleh merupakan ide yang unik, penyelesaian masalah dengan cara yang tidak biasa dan menggunakan situasi yang berbeda dari biasanya. Berpikir kreatif berkaitan dengan kemampuan untuk menciptakan sesuatu yang sudah ada menjadi sesuatu yang baru (Ridho et al, 2020). Kegiatan proyek memberikan situasi yang nyata bagi mahasiswa untuk mengembangkan keterampilan berpikir kreatif. Mahasiswa berusaha menyelesaikan masalah dan memberikan solusi dari permasalahan yang dihadapi (Yamin et al, 2020). Pembelajaran berbasis proyek didalam kegiatannya selalu ada diskusi, karena adanya diskusi dapat mengungkapkan ide dan gagasan. Kegiatan diskusi dilaksanakan diawal pembelajaran dan kegiatan inti. Aktivitas berdiskusi dilakukan dalam semua kegiatan pembelajaran berbasis proyek, dimulai dari pemberian pertanyaan mendasar, mendesain perencanaan proyek, menyusun jadwal, menguji hasil proyek hingga melaporkan hasil proyek (Kristanti et al, 2016).

Indikator elaboration dikembangkan melalui kemampuan mahasiswa menyimpulkan media yang tepat digunakan untuk pertumbuhan fitoplankton melalui kepadatan jumlah sel dengan lama waktu pertumbuhannya. Mahasiswa menghitung kepadatan sel fitoplankton pada hari ke-empat hingga hari ke-sembilan setelah penanaman starter. Hal ini diasumsikan bahwa hari pertama hingga hari ke-tiga fase adaptasi, jadi tidak perlu dilakukan perhitungan kepadatan sel, sedangkan pada hari ke-4 hingga hari ke-9 masuk fase eksponensial, stasioner dan kematian. Pembelajaran berbasis proyek yang 
memfokuskan pada elaboration ini sangat menarik. Hal ini disebabkan perwakilan setiap kelompok menyampaikan hasil pengamatan tentang perhitungan kepadatan sel fitoplankton, sehingga mahasiswa dapat menyimpulkan bahwa kepadatan sel dapat menentukan fase eksponensial dan kebutuhan nutrisi serta faktor-faktor eksternal yang diperlukan selama budidaya fitoplankton di laboratorium. Selain itu juga dapat mengembangkan dan memperkaya gagasan dari orang lain. Pendapat ini diperkuat oleh Bakir and Oztekin (2014) kemampuan elaboration dapat dikembangkan jika dapat melakukan analisis secara detail dan mendalam terhadap eksperimen yang dilakukan. Jika kemampuan elaborasi dilakukan dengan tepat, maka dapat menjadi sarana mahasiswa untuk mengkomunikasikan hasil proyeknya secara detail dan mendalam (Candra et al, 2019). Pembelajaran berbasis proyek, tidak hanya menuntut mahasiswa untuk mengidentifikasi masalah kemudian mencari solusinya, tetapi juga menuntut untuk menggabungkan pengetahuan dan keterampilan berpikir kreatif untuk menyelesaikan masalah (Ridho et al, 2020; Isabekov \& Sadyrova, 2018).

Berdasarkan hasil temuan penelitian ini memberikan manfaat untuk peningkatan keterampilan berpikir kreatif, ini terbukti bahwa terdapat beberapa mahasiswa yang mengambil mata kuliah ekologi laut menerbitkan artikel dan menyeminarkan secara nasional dari hasil kerja proyeknya. Pendapat ini sejalan dengan Ridho et al (2020) dan Husamah (2015) bahwa pembelajaran berbasis proyek telah memfasilitasi mahasiswa untuk mengembangkan diri baik secara akademis maupun praktis untuk menemukan solusi dalam kehidupan sehari-hari. Mengingat betapa pentingnya keterampilan berpikir kreatif yang harus dimiliki oleh peserta didik di era revolusi 4.0, agar dapat survive dalam menghadapi tantangan hidup, maka keterampilan berpikir kreatif terus dikembangkan baik di universitas maupun disekolah-sekolah melalui materi yang diajarkan.

\section{SIMPULAN}

Hasil penelitian ini menyimpulkan bahwa penerapan pembelajaran berbasis proyek pada materi biota laut menuju pembangunan berkelanjutan dapat meningkatkan keterampilan berpikir kreatif mahasiswa calon guru biologi. Mahasiswa dapat meningkatkan kemampuan berpikir kreatif melalui kegiatan desain proyeknya, yaitu budidaya fitoplankton di laboratorium, selain itu juga sebagai upaya untuk memecahkan dan memberikan solusi dari masalah yang hadapi. Peningkatan keterampilan berpikir kreatif dibuktikan dengan adanya perbedaan secara signifikan hasil belajar pretes dan postest dari ke-tiga indikator yaitu flexibility, originality dan elaboration.

Mengingat betapa pentingnya keterampilan berpikir kreatif dan pembelajaran berbasis proyek bagi peserta didik di abad $21 \mathrm{ini}$, pemerintah beserta praktisi pendidikan bersama-sama menyelenggarakan pelatihan dan sosialiasi terkait dengan manfaat dan cara pembelajaran eksakta khususnya IPA melalui pembelajaran berbasis proyek yang dilakukan secara berkesinambungan.

\section{DAFTAR PUSTAKA}

[1] Armandita, P., Wijayanto, E., Rofiatus, L., \& Susanti, N. (2017). Analisis keterampilan berpikir kreatif pembelajaran fisika di kelas XI MIA 3 SMA Negeri 11 Kota Jambi. Penelitian Ilmu Pendidikan, 10(2), 1-8.

[2] Bakir, S., \& Oztekin, E. (2014), Creative thinking levels of pre service science teacher in term of different variables, journal of baltic science education, 13(2), 12 
[3] Candra R.A, Prasetyab A.T., dan Hartatic R. (2019). analisis kemampuan berpikir kreatif peserta didik melalui penerapan blended project-based learning. Jurnal Inovasi Pendidikan Kimia, Vol 13, No 2, 2019, halaman 2437 - 2446.

[4] Colley, K. (2008). Project-based science instruction. The Science Teacher. 75 (8): 23-28.

[5] Diawati, C., Liliasari, dan Buchari B. (2017). Development and validation of creative thinking skills test in the project of laboratory apparatus modification. Ideas for 21st Century Education - Abdullah et al. (Eds) Taylor \& Francis Group. London, ISBN 978-1-138-05343-4.

[6] Ghanizadeh, A., Al-Hoorie, A. H., \& Jahedizadeh, S. (2020). Higher order thinking skills: In Second Language Learning and Teaching. Mashhad. Springer https://doi.org/10.1007/978-3-03056711-8_1

[7] Husamah, H. (2015). Thinking skills for environmental sustainability perspective of new students of biology education department through blended project based learning model. Jurnal Pendidikan IPA Indonesia, 4(2), 110-119, https://doi.org/10.15294/jpii.v4i2.3878.

[8] Isabekov, A., \& Sadyrova, G. (2018). Project-based learning to develop creative abilities in students. In J. Drummer, G. Hakimov, M. Joldoshov, T. Köhler, \& S. Udartseva (Eds.), Vocational Teacher Education in Central Asia: Developing Skills and Facilitating Success (pp. 43-49). Cham: Springer International Publishing, https://doi.org/10.1007/978-3-319-73093-6_4

[9] Jumrodah, S Liliasari and Y H Adisendjaja. (2019). Profile of pre-service biology teachers critical thinking skills based on learning project toward sustainable development. IOP Conf. Series: Journal of Physics: Conf. Series 1157 (2019) 022097. doi:10.1088/1742-6596/1157/2/022097

[10] Kristanti, Y. D., Subiki, dan Handayani, R. D. (2016). Model pembelajaran berbasis poject (project based learning model) pada pembelajaran fisika di SMA. Jurnal Pembelajaran Fisika, 5 (2): $122-128$.

[11] Lou, S., Chung, C., Dzan, W. \& Shih, R. (2012). Construction of a creative instructional design model using blended, Project-Based Learning for college students. Creative Education, 3(7): 12811290.

[12] Mulyono, Y. (2018). Improving creativity of the future physics teachers through general biology learning based on CTL with experimental method. Indonesian Journal of Science and Education, 2(1), 1-7.

[13] Rambely, A. S., Ahmad, R. R., Majid N., M-Suradi, N. R., Din, U. K. S., A-Rahman, I., Mohamed, F., Rahim, F. \& Abu-Hanifah, S. (2013). Project-based activity: root of research and creative thinking. International Education Studies, 6 (6).

[14] Rif'at, P.A.C., Wati, M., \& Suyidno, S. (2020). Developing Students' responsibility and scientific creativity through creative responsibility based learning in learning physics. Berkala Ilmiah Pendidikan Fisika, 8(1): 12-22.

[15] Ridlo Z.R., Nuha U, Terra I W A and Afafa L. (2019). The implementation of project-based learning in STEM activity (water filtration system) in improving creative thinking skill. Journal of Physics: Conference Series. 1563 (2020) 012073. doi:10.1088/1742-6596/1563/1/012073.

[16] Rosa N.M \& Nursa'adah F.P. (2017). Kontribusi laboratorium kimia dan sikap siswa terhadap pemanfaatan laboratorium terhadap keterampilan berpikir kritis dan kreatif. Jurnal Formatif, 7(3): 198-206.

[17] Santoso B.P., dan Wulandari F.E. (2020). Pengaruh pembelajaran berbasis proyek dipadu dengan metode pemecahan masalah pada keterampilan berpikir kreatif siswa. Journal of Banua Science Education, 1: (1). http://jbse.ulm.ac.id/index.php/JBSE.

[18] Sari D.K., Permanasari A., Supriyanti F.M.T. (2017). Profile of students' creative thinking skills on quantitative project-based protein testing using local materials. Jurnal Pendidikan IPA Indonesia. JPII 6 (1) (2017) 71-75. http://journal.unnes.ac.id/index.php/jpii.

[19] Susanti. (2013). Pengaruh pembelajaran berbasis proyek terhadap kemampuan berpikir kreatif dan sikap ilmiah siswa pada materi nutrisi. Jurnal Pengajaran MIPA, 18 (1): 36-42. 
[20] Sobri M., Nursaptini, Novitasari S. (2020). Mewujudkan kemandirian belajar melalui pembelajaran berbasis daring diperguruan tinggi pada era industri 4.0. Jurnal Pendidikan Glasser, 4 (1), doi:http://10.32529/glasser.v4i1.373.

[21] Tawil, M., \& Liliasari, L. (2013). Berpikir Kompleks dan Implementasinya dalam pembelajaran IPA. Makassar: Universitas Negeri Makassar.

[22] Torrance, E. P. (1966). Torrance tests of creative thinking: Norms-technical manual: Verbal tests, forms $a$ and $b$ : Figural tests, forms $a$ and $b$. Personal Press, Incorporated.

[23] Trnova, E. (2014). IBSE and creativity development. Science Education International, 25(1): 8-18

[24] UNESCO. (2017). Education for sustainable development goals learning objectives. The United Nations Educational, Scientific and Cultural Organization, 7, place de Fontenoy, 75352 Paris 07 SP, France ISBN 978-92-3-100209-0.

[25] Wahyudi, A. (2020). Profil keterampilan berpikir kritis dan kreatif calon guru kimia pada perkuliahan biokimia. Orbital: Jurnal Pendidikan Kimia, 4(2), 99-110.

[26] Wulandari N. A. D. \& Sukestiyarno. (2017). Development of OQALE based reference module for school geometry subject and analysis of mathematical creative thinking skills. Journal of Physics: Conference Series. Conf. Series 824 (2017) 012048. OP Publishing. doi:10.1088/17426596/824/1/012048.

[27] Xu, Y. Liu, W. (2010). A project-based learning approach: a case study in China. Asia Pacific Educ. Rev. 11:363-370, doi. 10.1007/s12564-010-9093-1.

[28] Yanti, L., Miriam, S., \& Suyidno. (2020). Mengembangkan keterampilan proses sains peserta didik melalui creative responsibility based learning. Jurnal Penelitian Pendidikan Sains, 9(2), 1790-1796.

[29] Yamin Y., Permanasari A., Redjeki S., and Sopandi W. (2020). Implementing project-based learning to enhance creative thinking skills on water pollution topic. Research Article. JPBI (Jurnal Pendidikan Biologi Indonesia), 6(2): 225-232.

[30] Zubaidah S. (2019). Memberdayakan keterampilan abad ke-21 melalui pembelajaran berbasis proyek. Seminar nasional nasional pendidikan biologi di FKIP Universitas Halu Oleo, Kendari, dengan Tema "Biologi dan Pembelajaran di Era Revolusi Industri 4.0", 12 Oktober 2019.

[31] Zainuddin., Suyidno., Dewantara, D., Mahtari, S., Nur, M., Yuanita, L., \& Sunarti, T. (2020). The correlation of scientific knowledge-science process skills and scientific creativity in creative responsibility based learning. International Journal of Instruction, 13(3): 307-316. 